\title{
Primary Mucoepidermoid Carcinoma of the Thyroid: A Report of a Rare Case with Bone Metastasis and Review of the Literature
}

\author{
Quang Van Le Duy Quoc Ngo Quy Xuan Ngo
}

Department of Head and Neck Surgery, Vietnam National Cancer Hospital, Hanoi, Vietnam

\section{Keywords}

Mucoepidermoid carcinomas · Thyroid · Mucoepidermoid · Bone metastasis

\begin{abstract}
Mucoepidermoid carcinomas (MECs) are generally found in salivary gland, but they have also been mentioned in other organs such as the larynx, esophagus, breast. MECs are considered to be a low-grade carcinoma and their occurrence in the thyroid is extremely rare. We present a 54-year-old male patient admitted to our clinic, complaining about having back pains for approximately three months. A lumbosacral spine MRI and a PET/CT scan revealed multiple lesions in the L4, L5, S1 vertebra bodies, sacral bone and left pelvis bone, suggesting of a metastatic disease. The result of thyroid FNA was carcinoma and a biopsy of the vertebra bone confirmed the presence of a metastatic carcinoma. A total thyroidectomy and level VI neck dissection was conducted followed by palliative external beam radiotherapy (30 Gy) to the vertebra bodies, sacral bone and left pelvis bone. In pathological studies, the diagnosis of thyroid mucoepidermoid carcinoma was confirmed.
\end{abstract}


Six months after treatment, the patient died due to severe pain and fatigue caused by the disease. Here, we report a rare case with bone metastasis as the first symptom of MEC and a brief review of published literature on the subject.

(C) 2019 The Author(s)

Published by S. Karger AG, Basel

\section{Introduction}

Mucoepidermoid carcinomas (MECs) are generally found in salivary gland, but they have also been mentioned in other organs such as the larynx, esophagus, breast. MECs are considered to be a low-grade carcinoma and their occurrence in the thyroid is extremely rare [1]. MEC of the thyroid were first described by Rhatigan et al., in 1977 and since then there have only been 46 documented cases found in the published literature, but they have a successful prognosis rate almost as good as MECs of the salivary gland, with only eight cases reported with poor prognosis so far [2-6].

Here, we report a case with bone metastasis as the first symptom of MEC and a brief review of published literature on the subject. We also report the ninth case with poor prognosis in which the patient passed away six months after the surgery.

\section{Case Report}

A 54-year-old male patient was admitted to our clinic, complaining about having back pains for approximately three months. The patient had no history of hypertension, diabetes mellitus, tuberculosis or any neck swelling, and neurological examination showed no abnormalities. A lumbosacral spine MRI (magnetic resonance image) scan revealed multiple lesions in the L4, L5, S1 vertebra bodies, sacral bone and left pelvis bone, suggesting of a metastatic disease (Fig. 1). A PET (positron emission tomography) scan showed abnormal hypermetabolic foci in the L4, L5, S1 vertebra bodies, sacral bone, left pelvis bone and left thyroid lobe, giving further indication of metastatic tissues (Fig. 2).

The patient had no previous history of neck irradiation and his family history was negative for any form of thyroid disease. Clinical examination of the neck using ultrasound revealed a left-sided nodule of $2 \mathrm{~cm}$ in size. Routine blood tests and thyroid function tests were also within normal limits. However, FNA (fine needle aspiration) of thyroid tumor and biopsy of the vertebra bone confirmed the presence of a metastatic carcinoma.

Once the carcinoma was confirmed, a total thyroidectomy and level VI neck dissection was conducted. Histology analysis revealed a microscopic focus of intrathyroidal low-grade MEC within the $2 \mathrm{~cm}$ nodule, as well as in one lymph node, however, no papillary features were identified. Postoperative, the patient was treated with palliative external beam radiotherapy (30 Gy) to the vertebra bodies, sacral bone and left pelvis bone to relieve pain. The patient did not receive radioactive iodine therapy. Six months after treatment, the patient died due to severe pain and fatigue caused by the disease.

In pathological studies that followed, there were no indicators of papillary carcinoma or follicular carcinoma, and no evidence of Hashimoto's thyroiditis in the thyroid parenchyma. Immunohistochemical analysis showed positive results for thyroglobulin, confirming that the 


\section{Case Reports in Oncology}

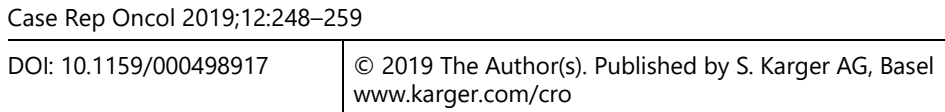

Le et al.: Primary Mucoepidermoid Carcinoma of the Thyroid: A Report of a Rare Case with Bone Metastasis and Review of the Literature

carcinoma primary origin site is the thyroid, and thus the diagnosis of thyroid mucoepidermoid carcinoma was confirmed (Fig. 3).

\section{Discussion}

Mucoepidermoid carcinomas (MECs) occur more commonly in the salivary gland, where approximately $10 \%$ of all salivary gland tumors are reported as benign MECs and approximately 35\% are reported as malignant MECs. However, MECs can also occur in other organs such as the larynx, esophagus, breast tissue, lungs, pancreas, and thyroid gland. From literature research and our experience, MEC of the thyroid are rarely occurrences, constituting less than $0.5 \%$ of all thyroid malignancies, and only 46 case reports in published literature since their first description by Rhatigan et al., in 1977 [2-6].

According to those 46 reported cases (Table 1, Table 2, Table 3, Table 4, Table 5) [2-15], occurrence of MEC is more commonly in females with a ratio of 1.56:1. Diagnosis age ranges from 10 to 91 years have been reported, with the mean being approximately 46.4 years. Patient with thyroid MEC show no symptoms of painless, while the tumor itself is usually a unilateral mass in the thyroid with reduced uptake in thyroid scans. The incidence rate of extrathyroidal extension is $14.8 \%$ (7/47 patients, including our case as the 47 th), and approximately $42.2 \%$ of patients have nodal metastases $(19 / 45$ patients, two patients were not included in the total of 47 patients). Because MEC could arise from de-differentiation of preexisting WDTC (papillary and follicular thyroid cancer) [12], the probability of nodal metastases occurrence would be high. However, in our case, there were no indicators of WDTC, Hashimoto's thyroiditis, however one of the four central compartment lymph nodes showed positive indicators of metastatic tissue post-surgery.

Although MECs are generally considered low-grade tumors, there have also been reports of high-grade variants, as well as several cases with metastasis to the esophagus, trachea, lungs, and liver [1]. However, primary thyroid MEC metastasis to the bone is a rare occurrence and has only been reported twice before in literature. In our study, the patient was initially admitted to our clinic with complaints of pain in the lumbar spine and left pelvis bone. PET and CT scans went on to reveal a mass on the left thyroid gland, as well as multiple metastasis at L4, L5, S1 spine bones and the left pelvis bone. Here, we present the third reported case of MEC metastases to bone at the time of diagnosis.

The histogenesis of thyroid MEC has been broadly debated in the reported literature. Initially, Rhatigan et al., 1977, suggested that MEC could originate from salivary gland rest, however, evidence for this has been uncertain, therefore this claim is largely disregarded [2].

Afterwards, it has been proposed that MECs derive from remnants of the ultimobranchial apparatus called the SCN (solid cell nest) [3]. However, positive results for immunohistochemical markers, such as TTF-1, PAX8, and calcitonin, contradict the SCN origin hypothesis and suggest the isthmus as the origin site [6].

Otherwise, many patients with concurrent WDTCs and MECs have been reported in the literature $[3,5,7,10]$. Pathological results reveal that WDTC may undergo squamous and mucinous metaplasia to give rise to MEC, therefore advocating the hypothesis that MEC originates from follicular epithelium. Among the 46 patients which have been reported, 20 of them have some form of relationship with WDTC (42.6\%). According to Prichard et al., authors suggest 
that most cases of MEC of the thyroid arise from metaplastic de-differentiation of WDTC rather than directly from benign squamous metaplasia, salivary gland rests, SCN, or thyroglossal duct remnants [12].

Surgical excision with total thyroidectomy plays an important role in treatment. However, a few selected patients managed successful by hemithyroidectomy were reported in the relevant literature [5]. The prophylactic central neck node dissection for patient with MEC is controversial [12]. External beam radiotherapy, chemotherapy have been used to treat MEC, however, there is still debate about adjuvant therapies [10-12]. In our study, postoperative, the patient was treated by palliative external radiotherapy to vertebra bodies, sacral bone and left pelvis bone for palliative purposes because he has metastased to bone at the time of diagnosis.

Most doctors acknowledge MEC of the thyroid as a low-grade malignant tumor. Prognosis for thyroid MEC is good, with several cases of disease-free survival of more than 10 years have been reported $[3,5]$. Nevertheless, most cases in published literature report patients diagnosed with locally advanced tumors in the form of local invasion or of cervical lymph node metastasis. Moreover, among the $46 \mathrm{MEC}$ cases reported so far, only 8 patients died between 2 to 13 months after diagnosis, two of whom had shown lung metastasis. In our case, the patient passed away six months after treatment due to severe pain and fatigue caused by the disease.

\section{Conclusion}

Mucoepidermoid carcinoma is a rare malignancy of the thyroid with only 46 cases reported to date. Although MEC of the thyroid is usually considered a low-grade malignant tumor, several cases with adverse outcomes have been reported. According to the past reports, only eight cases of thyroid MEC with poor prognosis were described. Herein, we have described a very rare case of thyroid MEC with metastasis to the bone with a poor prognostic result.

\section{Statement of Ethics}

The patient has given their written informed consent to publish their case (including publication of images). The study protocol was approved by the institute's committee on human research.

The authors have no ethical conflicts to disclose.

\section{Disclosure Statement}

The authors have no conflicts of interest to declare. 


\section{Funding Sources}

None.

\section{References}

1 Cameselle-Teijeiro J, Wenig B, Sobrinho-Simoes M, Albores- Saavedra J. Mucoepidermoid carcinoma. In: DeLellis RA, Lloyd RV, Heity PU, Eng C, editors. WHO Pathology and Genetics Tumours of Endocrine Organs. Lyon: IARC Press; 2004. pp. 82-3.

2 Rhatigan RM, Roque JL, Bucher RL. Mucoepidermoid carcinoma of the thyroid gland. Cancer. 1977 Jan;39(1):210-4.

3 Franssila KO, Harach HR, Wasenius VM. Mucoepidermoid carcinoma of the thyroid. Histopathology. 1984 Sep;8(5):847-60.

4 Tanda F, Massareui G, Bosincu L. Primary mucoepidermoid carcinoma of the thyroid. Surg Pathol. 2000;3:317-24.

5 Wenig BM, Adair CF, Heffess CS. Primary mucoepidermoid carcinoma of the thyroid gland: a report of six cases and a review of the literature of a follicular epithelial-derived tumor. Hum Pathol. 1995 Oct;26(10):1099-108.

6 Minagawa A, Iitaka M, Suzuki M, Yasuda S, Kameyama K, Shimada S, et al. A case of primary mucoepidermoid carcinoma of the thyroid: molecular evidence of its origin. Clin Endocrinol (Oxf). 2002 Oct;57(4):551-6.

7 Baloch ZW, Solomon AC, LiVolsi VA. Primary mucoepidermoid carcinoma and sclerosing mucoepidermoid carcinoma with eosinophilia of the thyroid gland: a report of nine cases. Mod Pathol. 2000 Jul;13(7):802-7.

8 Bhandarkar ND, Chan J, Strome M. A rare case of mucoepidermoid carcinoma of the thyroid. Am J Otolaryngol. 2005 Mar-Apr;26(2):138-41.

9 Ando M, Nakanishi Y, Asai M, Maeshima A, Matsuno Y. Mucoepidermoid carcinoma of the thyroid gland showing marked ciliation suggestive of its pathogenesis. Pathol Int. 2008 Nov;58(11):741-4.

10 Shindo K, Aishima S, Okido M, Ohshima A. A poor prognostic case of mucoepidermoid carcinoma of the thyroid: a case report. Case Rep Endocrinol. 2012;2012:862545.

11 Farhat NA, Faquin WC, Sadow PM. Primary mucoepidermoid carcinoma of the thyroid gland: a report of three cases and review of the literature. Endocr Pathol. 2013 Dec;24(4):229-33.

12 Prichard RS, Lee JC, Gill AJ, Sywak MS, Fingleton L, Robinson BG, et al. Mucoepidermoid carcinoma of the thyroid: a report of three cases and postulated histogenesis. Thyroid. 2012 Feb;22(2):205-9.

13 Obidike S, Aftab F. Rare Case of Mucoepidermoid Carcinoma of the Thyroid Gland. Thyroid Disorders Ther. 2016;5:199.

14 Taconet S, Bosq J, Hartl D, Schlumberger M, Leboulleux S, Scoazec JY, et al. Composite Mucoepidermoid Carcinoma and Columnar Cell Variant of Papillary Carcinoma of the Thyroid: A Case Report and Review of the Literature. Int J Surg Pathol. 2016 Jun;24(4):336-40.

15 Fulciniti F, Vuttariello E, Calise C, Monaco M, Pezzullo L, Chiofalo MG, et al. Combined papillary and mucoepidermoid carcinoma of the thyroid gland: a possible collision tumor diagnosed on fine-needle cytology. Report of a case with immunocytochemical and molecular correlations. Endocr Pathol. 2015 May;26(2):140-4. 


\section{Case Reports in Oncology}

Case Rep Oncol 2019;12:248-259

DOI: $10.1159 / 000498917$

(C) 2019 The Author(s). Published by S. Karger AG, Basel www.karger.com/cro

Le et al: Primary Mucoepidermoid Carcinoma of the Thyroid: A Report of a Rare Case with Bone Metastasis and Review of the Literature
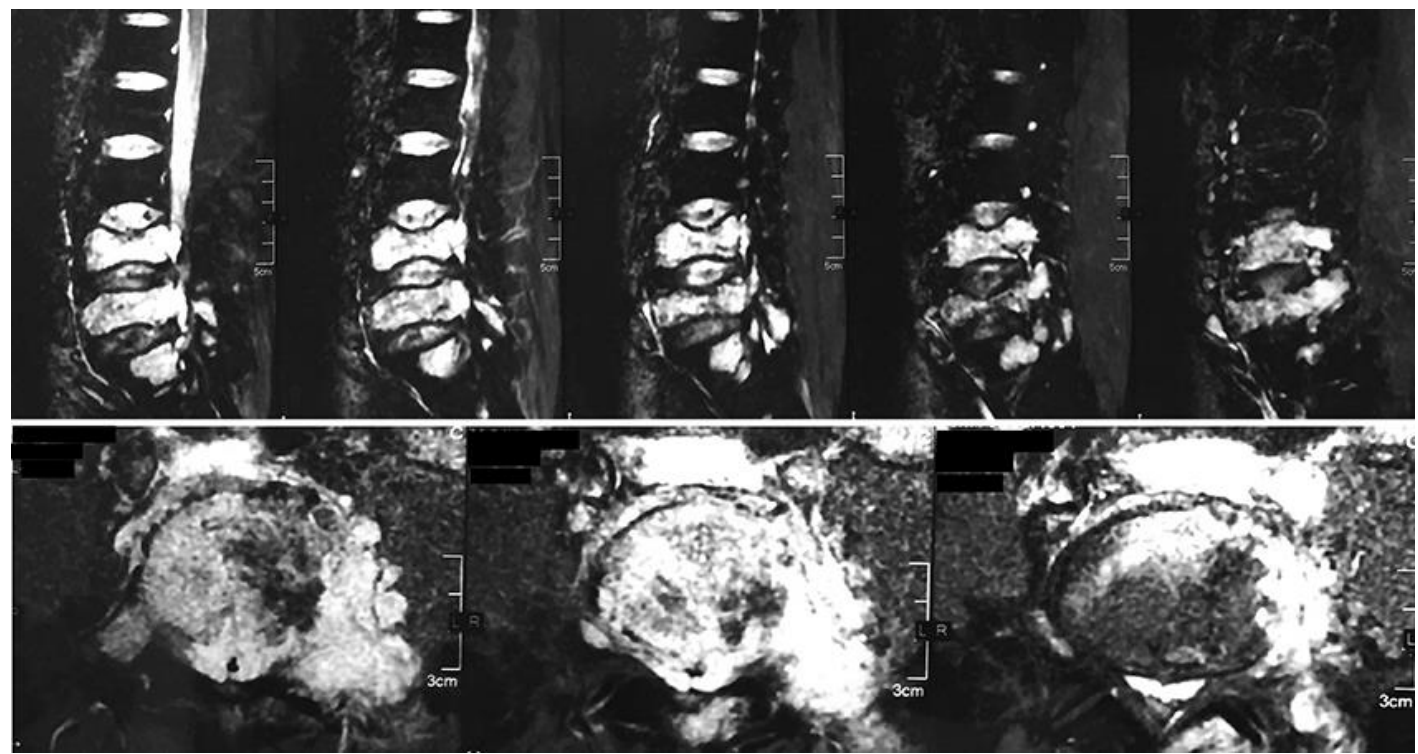

Fig. 1. A lumbosacral spine MRI scan revealed multiple lesions in the L4, L5, S1 vertebra bodies, sacral bone and left pelvis bone, suggesting of a metastatic disease.
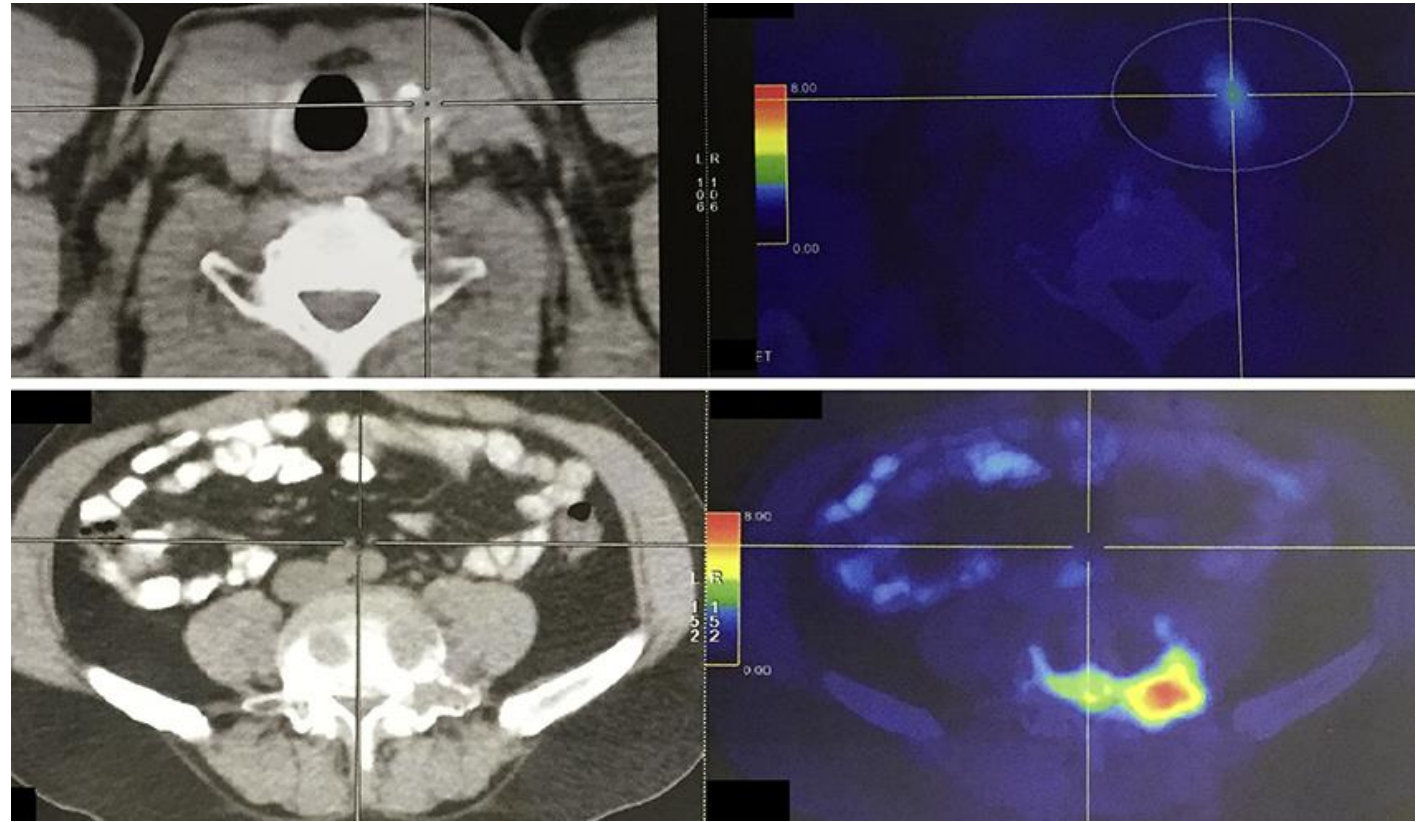

Fig. 2. A PET scan showed abnormal hypermetabolic foci in the L4, L5, S1 vertebra bodies, sacral bone, left pelvis bone and left thyroid lobe. 


\section{Case Reports in Oncology}

Case Rep Oncol 2019;12:248-259

DOI: $10.1159 / 000498917$

(C) 2019 The Author(s). Published by S. Karger AG, Basel www.karger.com/cro

Le et al.: Primary Mucoepidermoid Carcinoma of the Thyroid: A Report of a Rare Case with Bone Metastasis and Review of the Literature
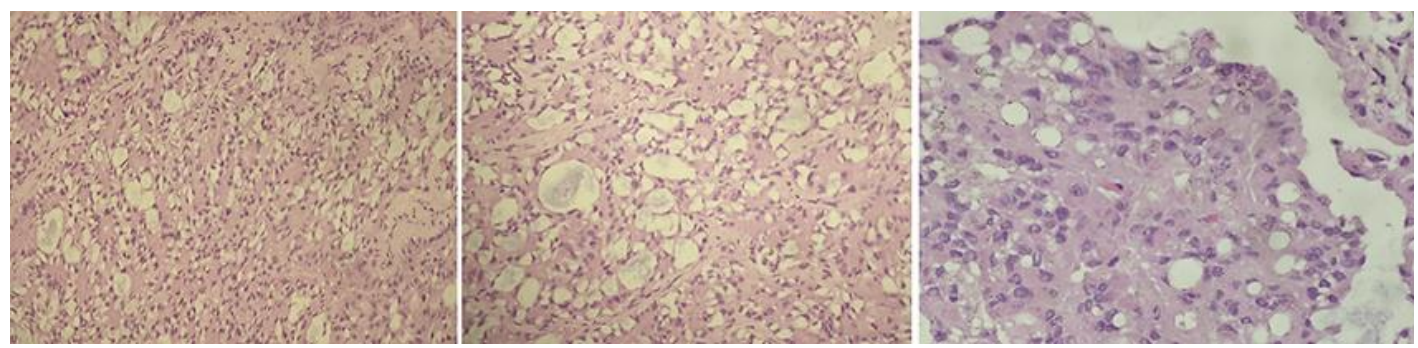

Fig. 3. Histology analysis revealed a low-grade MEC. 
Le et al.: Primary Mucoepidermoid Carcinoma of the Thyroid: A Report of a Rare Case with Bone Metastasis and Review of the Literature

Table 1. Literature review of thyroid mucoepidermoid carcinoma

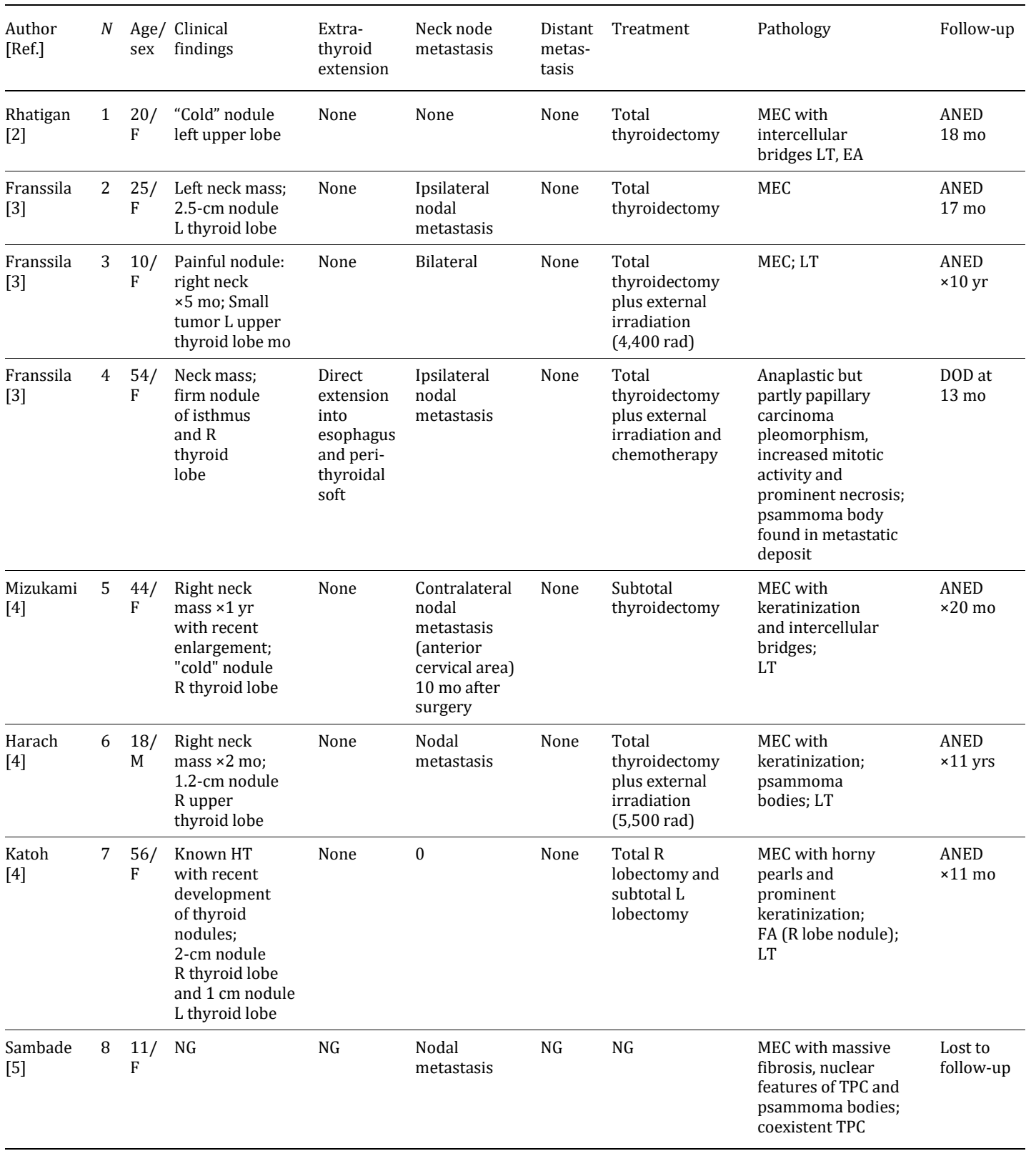

MEC, mucoepidermoid carcinoma; LT, lymphocytic thyroiditis; HT, Hashimoto's thyroiditis; FA, follicular adenoma; TPC, thyroid papillary carcinoma; AN, adenomatoid nodules; NG, not given; ANED, alive no evidence of disease; AWD, alive with disease; DOD, died of disease; R, right; L, left; mo, month; yr; year. 
Le et al.: Primary Mucoepidermoid Carcinoma of the Thyroid: A Report of a Rare Case with Bone Metastasis and Review of the Literature

Table 2. Literature review of thyroid mucoepidermoid carcinoma (continued)

\begin{tabular}{|c|c|c|c|c|c|c|c|c|c|}
\hline $\begin{array}{l}\text { Author } \\
\text { [Ref.] }\end{array}$ & $N$ & $\begin{array}{l}\text { Age/ } \\
\text { sex }\end{array}$ & $\begin{array}{l}\text { Clinical } \\
\text { findings }\end{array}$ & $\begin{array}{l}\text { Extra- } \\
\text { thyroid } \\
\text { extension }\end{array}$ & $\begin{array}{l}\text { Neck } \\
\text { node } \\
\text { metas- } \\
\text { tasis }\end{array}$ & $\begin{array}{l}\text { Distant } \\
\text { metas- } \\
\text { tasis }\end{array}$ & Treatment & Pathology & Follow-up \\
\hline $\begin{array}{l}\text { Sambade } \\
{[5]}\end{array}$ & 9 & $\begin{array}{l}20 / \\
\mathrm{F}\end{array}$ & NG & NG & $\begin{array}{l}\text { Nodal } \\
\text { metas- } \\
\text { tasis }\end{array}$ & $\begin{array}{l}\text { Nodal } \\
\text { metastasis; } \\
\text { pulmonary } \\
\text { metastasis } \\
7 \text { yrs after } \\
\text { diagnosis }\end{array}$ & NG & $\begin{array}{l}\text { MEC with nuclear } \\
\text { features of TPC and } \\
\text { psammoma bodies; } \\
\text { coexistent TPC }\end{array}$ & $\begin{array}{l}\text { AWD } \\
\times 22 \text { yrs }\end{array}$ \\
\hline $\begin{array}{l}\text { Sambade } \\
{[5]}\end{array}$ & 10 & $\begin{array}{l}67 / \\
F\end{array}$ & NG & NG & $\begin{array}{l}\text { Nodal } \\
\text { metas- } \\
\text { tasis }\end{array}$ & NG & NG & $\begin{array}{l}\text { MEC with nuclear } \\
\text { features of TPC; } \\
\text { coexistent TPC }\end{array}$ & $\begin{array}{l}\text { Lost to } \\
\text { follow-up }\end{array}$ \\
\hline $\begin{array}{l}\text { Sambade } \\
{[5]}\end{array}$ & 12 & $\begin{array}{l}58 / \\
F\end{array}$ & NG & NG & $\begin{array}{l}\text { Nodal } \\
\text { metas- } \\
\text { tasis }\end{array}$ & NG & NG & $\begin{array}{l}\text { MEC with nuclear } \\
\text { features of TPC and } \\
\text { psammoma bodies; } \\
\text { coexistent TPC }\end{array}$ & $\begin{array}{l}\text { Dead } 10 \\
\text { days post- } \\
\text { operatively }\end{array}$ \\
\hline $\begin{array}{l}\text { Sambade } \\
{[5]}\end{array}$ & 13 & $\begin{array}{l}15 / \\
M\end{array}$ & NG & NG & $\begin{array}{l}\text { Nodal } \\
\text { metas- } \\
\text { tasis }\end{array}$ & NG & NG & $\begin{array}{l}\text { MEC with nuclear } \\
\text { features of TPC; LT }\end{array}$ & $\begin{array}{l}\text { ANED } \\
\times 6 \mathrm{mo}\end{array}$ \\
\hline $\begin{array}{l}\text { Sambade } \\
{[5]}\end{array}$ & 14 & $\begin{array}{l}47 / \\
M\end{array}$ & NG & None & None & None & NG & $\begin{array}{l}\text { MEC with nuclear } \\
\text { features of TPC; LT }\end{array}$ & $\begin{array}{l}\text { ANED } \\
\times 20 \text { mo }\end{array}$ \\
\hline Tanda [5] & 15 & $\begin{array}{l}33 / \\
M\end{array}$ & $\begin{array}{l}\text { Painless mass } \\
\text { L neck } \times 4 \mathrm{mo} \text {; } \\
\text { "cold" nodule } \\
\text { measuring } 6 \times 3 \mathrm{~cm} \\
\text { in R thyroid lobe }\end{array}$ & None & None & None & $\begin{array}{l}\text { R hemithy- } \\
\text { roidectomy }\end{array}$ & $\begin{array}{l}\text { MEC with } \\
\text { associated; } \\
\text { ciliated epithelium }\end{array}$ & $\begin{array}{l}\text { ANED } \\
\times 24 \mathrm{mo}\end{array}$ \\
\hline $\begin{array}{l}\text { Larson } \\
{[5]}\end{array}$ & 17 & $\begin{array}{l}61 / \\
F\end{array}$ & $\begin{array}{l}\text { Dyspnea } \times 2 \text { mo } \\
\text { with R pleural } \\
\text { effusion; recent } \\
\text { onset of R hip } \\
\text { pain; an } \\
\text { immovable R } \\
\text { thyroid lobe } \\
\text { nodule was found } \\
\text { associated with } \\
\text { tracheal deviation }\end{array}$ & None & None & $\begin{array}{l}\text { Metastasis } \\
\text { to pleura } \\
\text { and bone } \\
\text { (thoracic } \\
\text { vertebrae) }\end{array}$ & $\begin{array}{l}\text { Radiotherapy; } \\
\text { recent } \\
\text { case }\end{array}$ & $\begin{array}{l}\text { MEC diagnosed by } \\
\text { FNA; incisional } \\
\text { biopsy of pleural } \\
\text { metastasis showed } \\
\text { a MEC with keratin } \\
\text { pearls }\end{array}$ & NG \\
\hline
\end{tabular}

MEC, mucoepidermoid carcinoma; LT, lymphocytic thyroiditis; HT, Hashimoto's thyroiditis; FA, follicular adenoma; TPC, thyroid papillary carcinoma; AN, adenomatoid nodules; NG, not given; ANED, alive no evidence of disease; AWD, alive with disease; DOD, died of disease; R, right; L, left; mo, month; yr; year. 
Table 3. Literature review of thyroid mucoepidermoid carcinoma (continued)

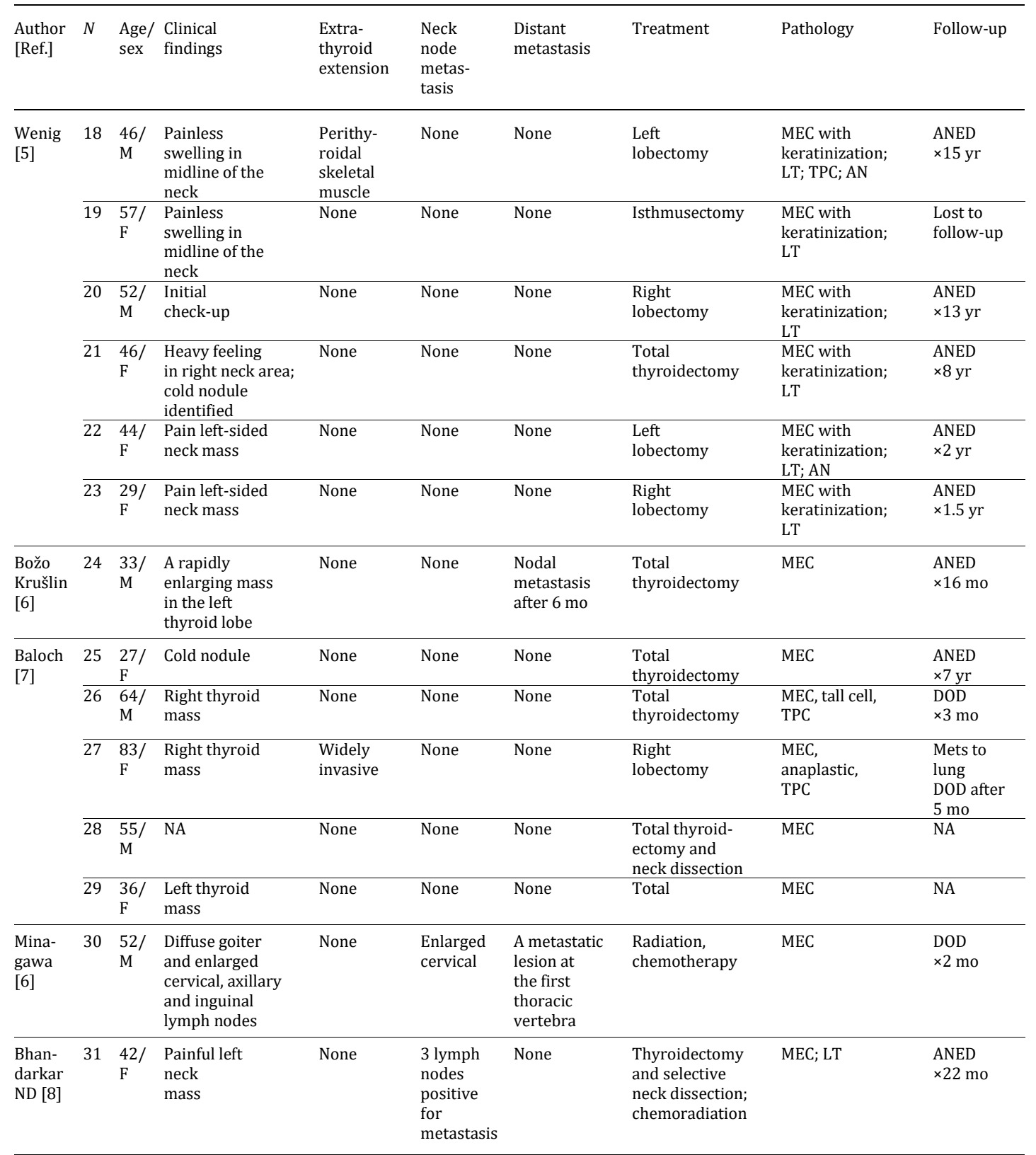

MEC, mucoepidermoid carcinoma; LT, lymphocytic thyroiditis; HT, Hashimoto's thyroiditis; FA, follicular adenoma; TPC, thyroid papillary carcinoma; AN, adenomatoid nodules; NG, not given; ANED, alive no evidence of disease; AWD, alive with disease; DOD, died of disease; R, right; L, left; mo, month; yr; year. 
Table 4. Literature review of thyroid mucoepidermoid carcinoma (continued)

\begin{tabular}{|c|c|c|c|c|c|c|c|c|c|}
\hline $\begin{array}{l}\text { Author } \\
\text { [Ref.] }\end{array}$ & $N$ & $\begin{array}{l}\text { Age/ } \\
\text { sex }\end{array}$ & $\begin{array}{l}\text { Clinical } \\
\text { findings }\end{array}$ & $\begin{array}{l}\text { Extra- } \\
\text { thyroid } \\
\text { extension }\end{array}$ & $\begin{array}{l}\text { Neck node } \\
\text { metastasis }\end{array}$ & $\begin{array}{l}\text { Distant } \\
\text { metas- } \\
\text { tasis }\end{array}$ & Treatment & Pathology & Follow-up \\
\hline \multirow{2}{*}{$\begin{array}{l}\text { Farhat } \\
\text { NA [11] }\end{array}$} & $\overline{35}$ & $\begin{array}{l}63 / \\
F\end{array}$ & $\begin{array}{l}\text { Nodule in } \\
\text { the left } \\
\text { lower lobe }\end{array}$ & None & None & None & Total & $\begin{array}{l}\text { MEC, } \\
\text { TPC }\end{array}$ & $\begin{array}{l}\text { ANED } \\
\times 11 \mathrm{mo}\end{array}$ \\
\hline & $\overline{36}$ & $\begin{array}{l}65 / \\
F\end{array}$ & $\begin{array}{l}\text { Nodule in } \\
\text { the left } \\
\text { lower lobe }\end{array}$ & None & None & None & Total & MEC & $\begin{array}{l}\text { ANED } \\
\times 3 \mathrm{yr}\end{array}$ \\
\hline \multirow[t]{2}{*}{$\begin{array}{l}\text { Prichard } \\
\text { RS [12] }\end{array}$} & 37 & $\begin{array}{l}22 / \\
\mathrm{F}\end{array}$ & $\begin{array}{l}\text { Left-sided } \\
\text { thyroid } \\
\text { nodule } \\
\text { during } \\
\text { her first } \\
\text { pregnancy }\end{array}$ & None & None & None & $\begin{array}{l}\text { Total, radioactive } \\
\text { iodine and } \\
\text { thyroxine } \\
\text { suppression }\end{array}$ & $\begin{array}{l}\text { MEC, } \\
\text { TPC }\end{array}$ & $\begin{array}{l}\text { NA } \\
1 \text { yr later } \\
\text { with a } \\
\text { palpable } \\
\text { nodule in the } \\
\text { left lateral } \\
\text { jugular chain }\end{array}$ \\
\hline & 39 & $\begin{array}{l}58 / \\
M\end{array}$ & $\begin{array}{l}\text { Progressive } \\
\text { dyspnea }\end{array}$ & None & None & None & $\begin{array}{l}\text { Total thyroidectomy, } \\
\text { radioactive iodine } \\
\text { ablation and } \\
\text { thyroxine } \\
\text { suppression }\end{array}$ & MEC & $\begin{array}{l}\text { ANED } \\
\times 6 \mathrm{mo}\end{array}$ \\
\hline $\begin{array}{l}\text { Obidike } \\
\text { S [13] }\end{array}$ & 40 & $\begin{array}{l}64 / \\
F\end{array}$ & $\begin{array}{l}\text { Small lump } \\
\text { on the left } \\
\text { side of her } \\
\text { neck }\end{array}$ & None & None & None & Total & MEC & NA \\
\hline
\end{tabular}

MEC, mucoepidermoid carcinoma; LT, lymphocytic thyroiditis; HT, Hashimoto's thyroiditis; FA, follicular adenoma; TPC, thyroid papillary carcinoma; AN, adenomatoid nodules; NG, not given; ANED, alive no evidence of disease; AWD, alive with disease; DOD, died of disease; R, right; L, left; mo, month; yr; year. 
Table 5. Literature review of thyroid mucoepidermoid carcinoma (continued)

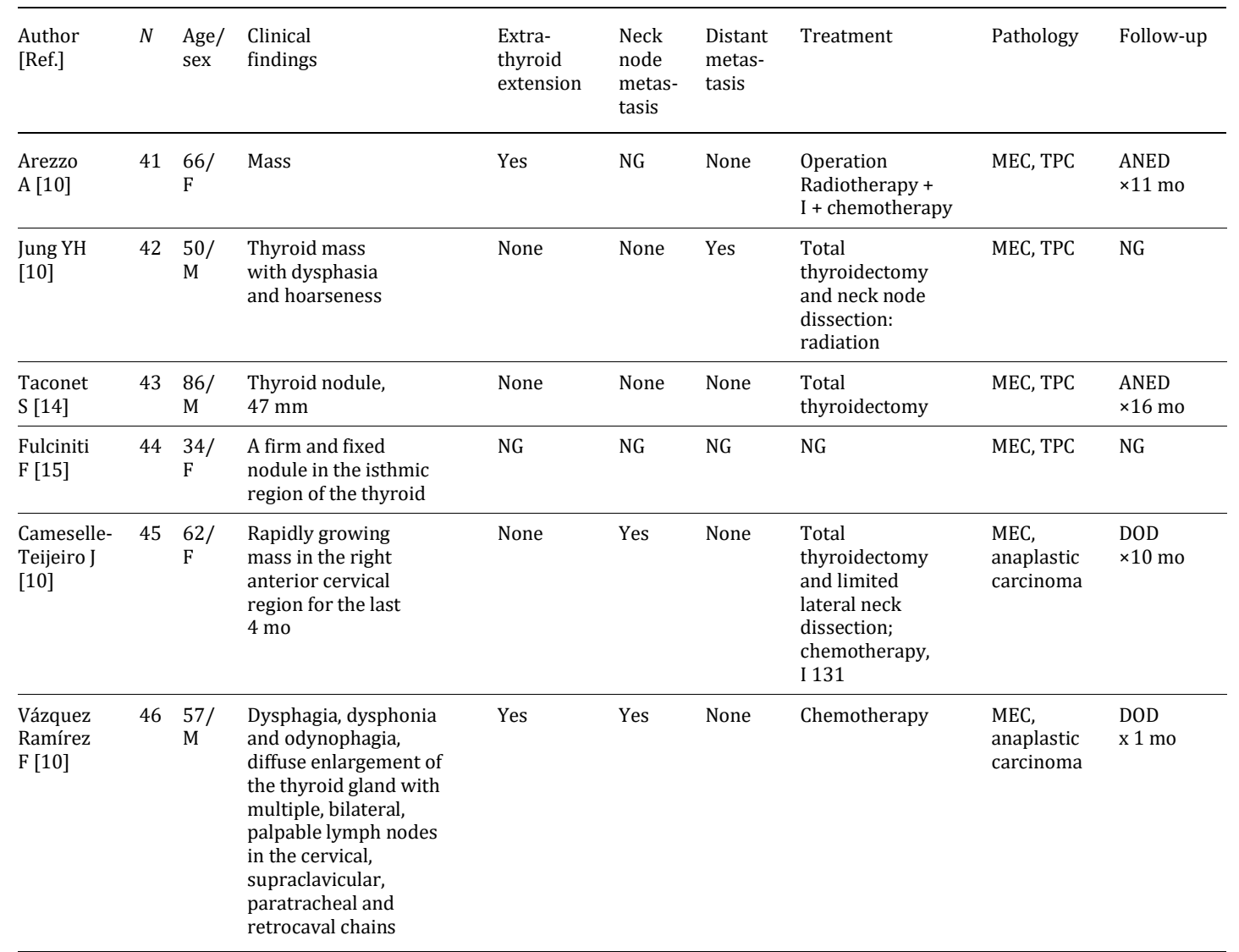

MEC, mucoepidermoid carcinoma; LT, lymphocytic thyroiditis; HT, Hashimoto's thyroiditis; FA, follicular adenoma; TPC, thyroid papillary carcinoma; AN, adenomatoid nodules; NG, not given; ANED, alive no evidence of disease; AWD, alive with disease; DOD, died of disease; R, right; L, left; mo, month; yr; year. 